\title{
INFORMATION VERIFICATION DURING COVID-19. COMPARATIVE ANALYSIS \\ IN SOUTHERN EUROPEAN COUNTRIES
}

RAÚL MAGALLÓN-ROSA

raul.magallon@uc3m.es

Raúl Magallón Rosa works as a professor of journalism in the Department of Communication of

Carlos III University of Madrid (Spain). He has a degree in Journalism and a Ph.D. with a European component from Complutense University of Madrid. His research strand focuses on the relationship between disinformation and fact-checking. He is the author of "Unfaking News. How to fight disinformation" (also published in Portuguese) and "Disinformation and pandemic. The new reality". (Unfaking News. Cómo combatir la desinformación" and "Desinformación y pandemia. La nueva realidad").

\section{JOSÉ MANUEL SÁNCHEZ-DUARTE}

josemanuel.sanchez@urjc.es

He has a degree in Sociology from the University of Salamanca, a Ph.D. in Communication from the Rey Juan Carlos University, and a Ph.D. in Social Sciences (political specialty) from the Pontificia Universidade Católica de São Paulo. He is a Professor of Political Communication at Rey Juan Carlos University (Spain) and Deputy Secretary General of the Menéndez Pelayo International University.

\begin{abstract}
Disinformation poses a challenge for democracies, especially in exceptional periods such as electoral processes but, above all, as a consequence of a global health crisis with no clear end date. The objective of this research is to analyse the type of hoaxes identified during the COVID-19 pandemic in southern European countries (Portugal, Spain, Italy and Greece). To this effect, 936 pieces of disinformation reported by the main verification organizations in those countries were examined between February and August 2020: Observador and Polígrafo (Portugal), Newtral, Maldita and EFE verifica (Spain) Facta, Open, Effecinque and Pagella Politica (Italy) and Ellinika Hoaxes (Greece). As a final conclusion, the presence or absence of a common pattern in the four countries is examined based on the topic of the hoaxes, their distribution channels and how viral they spread abroad. Two axes of disinformation were established: one health-preventive and the other in terms of political polarization.
\end{abstract}

\section{Keywords}

Disinformation, fact-checking, COVID-19, polarization, Europe.

\section{How to cite this article}

Magallón-Rosa, Raúl; Sánchez-Duarte, José Manuel. Information verification during COVID19. Comparative analysis in Southern European Countries. Thematic dossier International Relations and Social Networks, July 2021. Consulted [online] on date of last visit, https://doi.org/10.26619/1647-7251.DT21.10

Article received on December 30, 2020 and accepted for publication on March 19, 2021

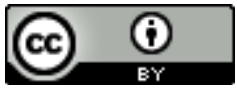




\title{
INFORMATION VERIFICATION DURING COVID-19. COMPARATIVE ANALYSIS IN SOUTHERN EUROPEAN COUNTRIES ${ }^{1}$
}

\author{
RAÚL MAGALLÓN-ROSA \\ JOSÉ MANUEL SÁNCHEZ-DUARTE
}

\section{Introduction ${ }^{2}$}

The crisis arising from COVID-19 has been a challenge health wise, and also regarding economic and social terms and management of (dis)information. The objective of this work is to analyse the hoaxes identified during the first six months of the pandemic in southern European countries (Portugal, Spain, Italy and Greece). The selection of these countries was due to the fact that they share the same relationship pattern between the political and media systems (Hallin and Mancini, 2004; Brüggemann et a/t., 2014; Büchel et al. 2016).

In this regard, authors such as Humprecht point out that these types of countries stand out due to their comparatively high levels of social polarization, populist communication and high use of social networks for news consumption. Similarly, countries in this group tend to have lower levels of trust in the media (Humprecht et a/t., 2019).

In Portugal, the first cases were registered on 2 March 2020. Two weeks later, the government closed the border with Spain and decreed a state of emergency (between 17 and 18 March). In Spain, the first case was reported on 31 January. On 12 February, the Mobile World Congress in Barcelona was cancelled and a month later, on 12 March, the Government announced the first measures to stop the pandemic.

On 14 March, the state of alarm was declared alongside the lockdown of the population. In Greece, the first case was registered on 24 February, and the closure was decreed on 23 March. Italy was the first European country hit by COVID-19. The first cases were registered on 30 January 2020. On 8 March, the quarantine was extended to cover the

Article translated by Carolina Peralta.

This work has been carried out thanks to a Research Grant signed with The Poynter Institute for Media Studies ("Poynter"). By accessing the \#Coronavirusfacts database of the International Factckecking Network (IFCN), we have been able to carry out this comparative study. 
entire Lombardy region, in addition to 14 northern Italian provinces (Peña-Ascacibar et a/t, 2021).

On 31 August 2020, 462,858 cases were confirmed in Spain, 10,317 in Greece, 269,214 in Italy and 58,012 in Portugal.

Graph 1. "Cumulative confirmed COVID-19 cases"

\section{Cumulative confirmed COVID-19 cases}

The number of confirmed cases is lower than the number of actual cases; the main reason for that is limited testing.

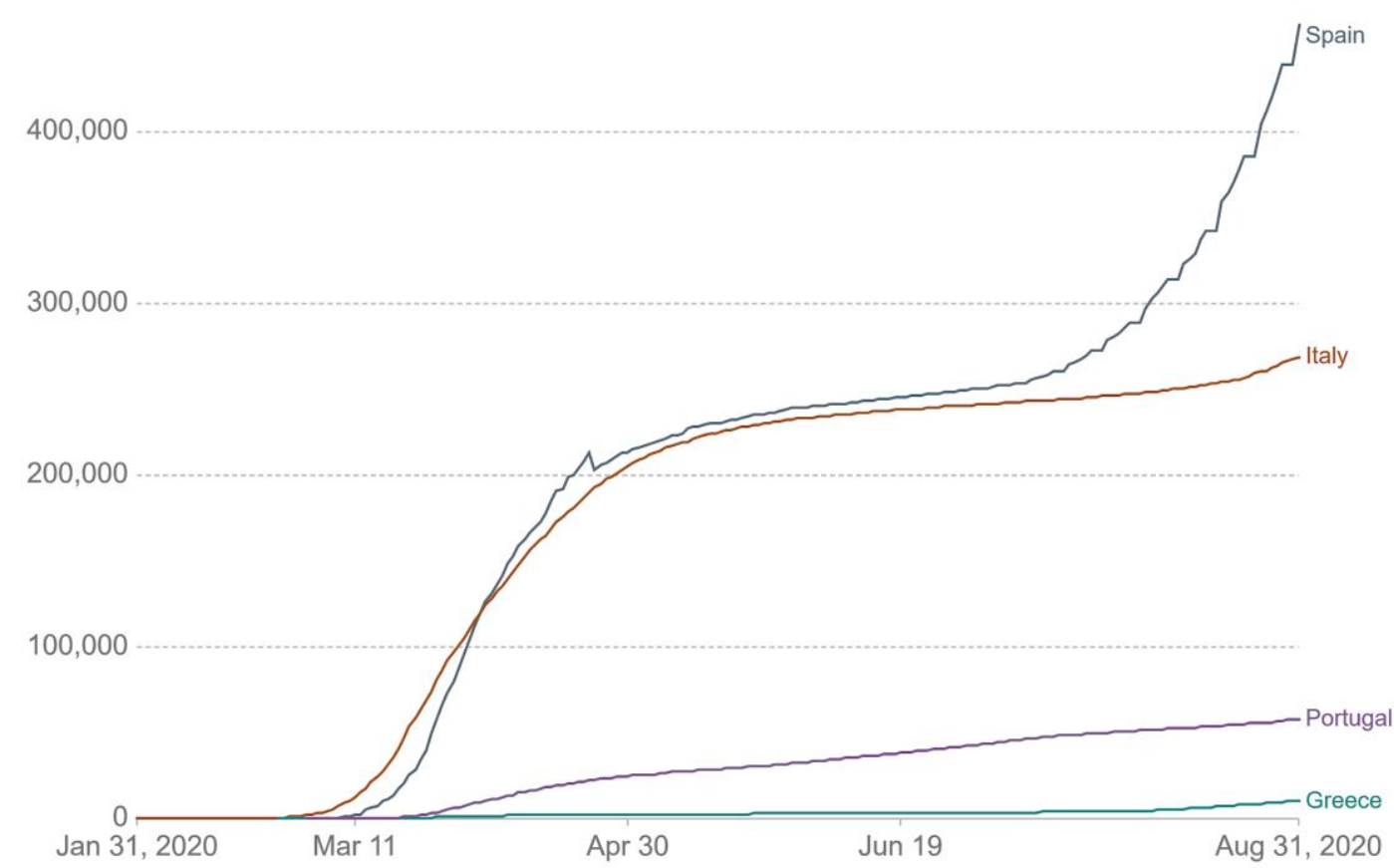

Source: Our World Data.

Infodemic (Nielsen et al., 2020), tsunami of misinformation or information saturation (Tangcharoensathien et alt., 2020) are some of the concepts and problems that were linked to media and information consumption during the first months of the COVID-19 pandemic (Brennen et al., 2020; Papapicco, 2020). From an information point of view, these studies have had an impact on the relationship between risk communication and communicating risk (Lozano, 2008), but also on information saturation or fatigue.

As indicated by the WHO, such fatigue can be described as: "the lack of motivation to follow the recommended protective behaviours that appears gradually over time and is affected by various emotions, experiences and perceptions, as well as by the social, cultural, structural and legislative context". ${ }^{3}$

3 See: https://apps.who.int/iris/bitstream/handle/10665/335820/WHO-EURO-2020-1160-40906-55390eng.pdf 
It is not new that, in periods of high information intensity and unforeseen events of indeterminate duration, citizens urgently need to expand their data and obtain details about the events narrated in the news. What is new is that social networks, instant messaging systems and the use of political actors who use lies as tactic and deception as a strategy have developed an information ecosystem that is often off the radar of the media and complementary to the latter as manager and producer of information (Sánchez-Duarte and Magallón-Rosa, 2020a, López-Pan and Rodríguez-Rodríguez, 2020, Vizoso \& Vázquez-Herrero, 2019).

In this sense, the approach to the phenomenon of disinformation (Wardle and Derakshan, 2017) has become increasingly specialized and glocal, compared to the first research that sought to take a still photograph of a historical event in permanent motion. Claire Wardle and Hossein Derakhshan published a report in September $(2017,5)$ entitled The Information Disorder: Towards an Interdisciplinary Framework for Research and Policy Making, in which they stated:

We refrain from using the term 'fake news', for two reasons. First of all, it is woefully inadequate to describe the complex phenomenon of information pollution. The term has also begun to be appropriated by politicians around the world to describe news organisations whose coverage they find disagreeable. In this way, it is becoming the mechanism by which the powerful can clamp down, restrict, undermine and circumvent the free press.

From this point of view, it is necessary to point out that the disinformation cycle is adaptive and linked to eventual and opportunistic niches based on confusion, media deficiencies and information saturation.

Beyond the lack of coordination between administrations, the rise of conspiracy theories (Uscinski et al., 2020) and the development of anti-vaccine campaigns, perhaps the most relevant fact has been that the pandemic has acted as a catalyst for polarization in many countries. In this sense, the first research works are showing how belonging and affinity to certain political options is related to having a position in favour or against COVID-19 vaccination. At the same time, the first works that link polarization, disinformation and the predisposition to vaccinate have been published (Loomba et a/t., 2021).

According to Brennen's work (2020), disinformation from well-known promoters such as politicians, celebrities, and other prominent public figures accounted for 20 percent of his analysis but made-up 69 percent of total social media interactions. Therefore, and despite the initial anonymity and the impossibility of often identifying the origin of hoaxes, their extreme viral spread is caused by recognized promoters who consciously or unconsciously spread the messages.

Authors such as Sánchez-Duarte and Magallón-Rosa (2020b) established a typology of hoaxes that circulated in the first months of the pandemic based on four categories: infections, status and evolution of the pandemic; forms of prevention and cures; measures (public and private) adopted in the fight against the pandemic and to alleviate its effects and others. 
Table 1. Typology of hoaxes.

\begin{tabular}{|l|l|}
\hline \multicolumn{1}{|c|}{ Typology of hoaxes } & \multicolumn{1}{c|}{ Examples } \\
\hline Contagion & $\begin{array}{l}\text { Condition and evolution of those infected, numbers, } \\
\text { contagion areas, specific situations of localities with } \\
\text { contagious sources, evolution of the disease, situations } \\
\text { of chaos, characteristics and symptoms. }\end{array}$ \\
\hline Prevention & Forms and methods of prevention, cures, drugs, etc. \\
\hline $\begin{array}{l}\text { Measures (public and private) } \\
\text { adopted in the fight against the } \\
\text { pandemic and to mitigate its effects }\end{array}$ & $\begin{array}{l}\text { Closure of spaces, control and restriction measures, } \\
\text { orders by government and political parties, prohibitions, } \\
\text { presence of the army, actions taken by companies, etc. }\end{array}$ \\
\hline Other & $\begin{array}{l}\text { Issues related to security (burglaries, computer security, } \\
\text { scams (phishing), theories about the origin of the virus, } \\
\text { predictions about the arrival of the pandemic, } \\
\text { information on specific population groups, etc. }\end{array}$ \\
\hline
\end{tabular}

Source: Sánchez-Duarte and Magallón-Rosa (2020b).

They also analysed the origin and distribution channels of the hoaxes (social networks, instant messaging or the media), the intent of the hoax (deny or expand information), their possible viral spread in other countries and whether it was possible to identify the promoters of the hoaxes.

From this point of view, a study on southern European countries is essential for two reasons. In the first place, because of the predominance of studies on Anglo-Saxon countries compared to other languages and cultures and because of the traditional polarized nature of southern European countries.

Regarding the information gap related to studies on disinformation, it should be noted that the work by Seo and Faris (2021) highlights that $62.8 \%$ of the academic works published between January 2015 and October 2020 were carried out with data from the US. In quantitative terms, computational social science methods, experiments, and surveys were the dominant approaches. The experiments accounted for $23.8 \%$ of the articles analysed, followed by computational social science methods (18.1\%), surveys $(15.2 \%)$, interviews or focus groups $(14.3 \%)$, human-based or textual analysis coded content analysis (11.4\%) and meta-analysis or secondary data analysis (9.5\%). Other methods $(7.7 \%)$ included image analysis, ethnography, and case studies. Thus, the combination of methodologies for the analysis and study of fact-checking (López et alt, 2020; Freiling et a/t. 2020), disinformation (Aguado and Bernaola, 2020; Apuke and Omar, 2020) and regional characteristics and individuals from each country are essential to conduct a comparative analysis capable of establishing analogies, relationships and, of course, knowledge. 


\section{Method}

This research is focused on describing the disinformation identified by the verification organizations of Portugal, Spain, Italy and Greece in the first months of the COVID-19 pandemic (March- August 2020).

The choice of these countries is justified because since the beginning of the health crisis, and with different intensities depending on the waves of contagion:

1) They share a region (southern Europe)

2) They share the relationship model of the political and media systems (Hallin and Mancini, 2004)

3) They present different levels of incidence of the pandemic. This internal divergence between the most affected (Spain and Italy) and the least (Portugal and Greece) allows us to identify, in a descriptive way, the extent to which disinformation had greater impact in situations and geographical contexts with more accentuated crises.

For the analysis, the disinformation pieces reported by fact-checking organizations from these countries to the verification platform of the International Fact Checking Network $(\mathrm{IFCN})^{4}$ were selected.

This network, dependent on the Poynter Institute, was created in 2015 with the aim of "bringing together data verification initiatives by promoting and exchanging good practices". During the COVID-19 pandemic, the IFCN launched the \#CoronavirusFacts Alliance initiative, bringing together more than 100 verifiers from around the world to "share, translate and publish" new coronavirus data".

In the same way, this alliance has made it possible to monitor in real time and simultaneously - in very different countries and completely antagonistic information cultures - how hoaxes, rumours, erroneous information, propaganda or false information circulated. It also enabled analysing in a much more complete way how the narratives circulated disinformation worldwide (Marin, 2020) and adapted to national, cultural and local contexts (Naeem and Bhatti, 2020; Salaverria et alt., 2020).

Based on the IFCN database, 936 pieces of disinformation reported by the main verification organizations in Portugal, Spain, Italy and Greece were selected: Observador, Polígrafo, Newtral, Maldita, Open, Effecinque, Facta, Pagella Politica and Ellinika Hoaxes. The number of hoaxes in each of the countries was distributed as follows:

See: https://www.poynter.org/ifcn/ [Accessed on 09/02/2021]

See: https://www.poynter.org/coronavirusfactsalliance/ [Accessed on 09/02/2021] 
Table 2: Number of pieces of disinformation in Portugal, Spain, Italy and Greece between March and August 2020

\begin{tabular}{|l|r|}
\hline \multicolumn{1}{|c|}{ Country } & \multicolumn{1}{|c|}{ Number of pieces of disinformation } \\
\hline Portugal & 88 \\
\hline Spain & 574 \\
\hline Italy & 209 \\
\hline Greece & 65 \\
\hline Total & $\mathbf{9 3 6}$ \\
\hline
\end{tabular}

Source: International Fact Checking Network.

After being identified, these pieces of disinformation formed a data matrix organized according to the following variables:

- Evolution by months: hoaxes in the four countries (between March and August).

- Subject categories: authorities (information related to political or government actions), causes, symptoms and cures (information focused on health aspects), conspiracy theories (hoaxes that addressed the origin of the pandemic and its management based on conspiracy theories), propagation (evolution in regions, cities, expansion by geographical areas, etc.) and others (category with diverse and personalized disinformation in each of the countries in the presence of celebrities, questions about security, etc.).

- Qualification of disinformation: false (complete false disinformation) or misleading (disinformation with aspects that did not conform to reality or half-truths).

- Degree of viral spread in other countries: disinformation replicated or not in other countries.

Based on these variables, a descriptive analysis of the disinformation identified in the four countries was carried out. Although this technique has certain limits, it is relevant when exploring trends and laying the groundwork for future research.

\section{Results}

From the comparative analysis presented here, we can establish some clear results and learnings. The months of March and April were the most active from the point of view of disinformation, and consequently, of the verifications made by the fact-checkers.

In Portugal, they account for $58.4 \%$ of verifications, in Spain $57.7 \%$, in Greece $59.6 \%$ and the only exception is Italy where only $33.7 \%$ of verifications were recorded.

In Italy, the month of May stood out, when $29.7 \%$ of circulating hoaxes were identified. 
Graph 2. Evolution of disinformation by country between February and August 2020.

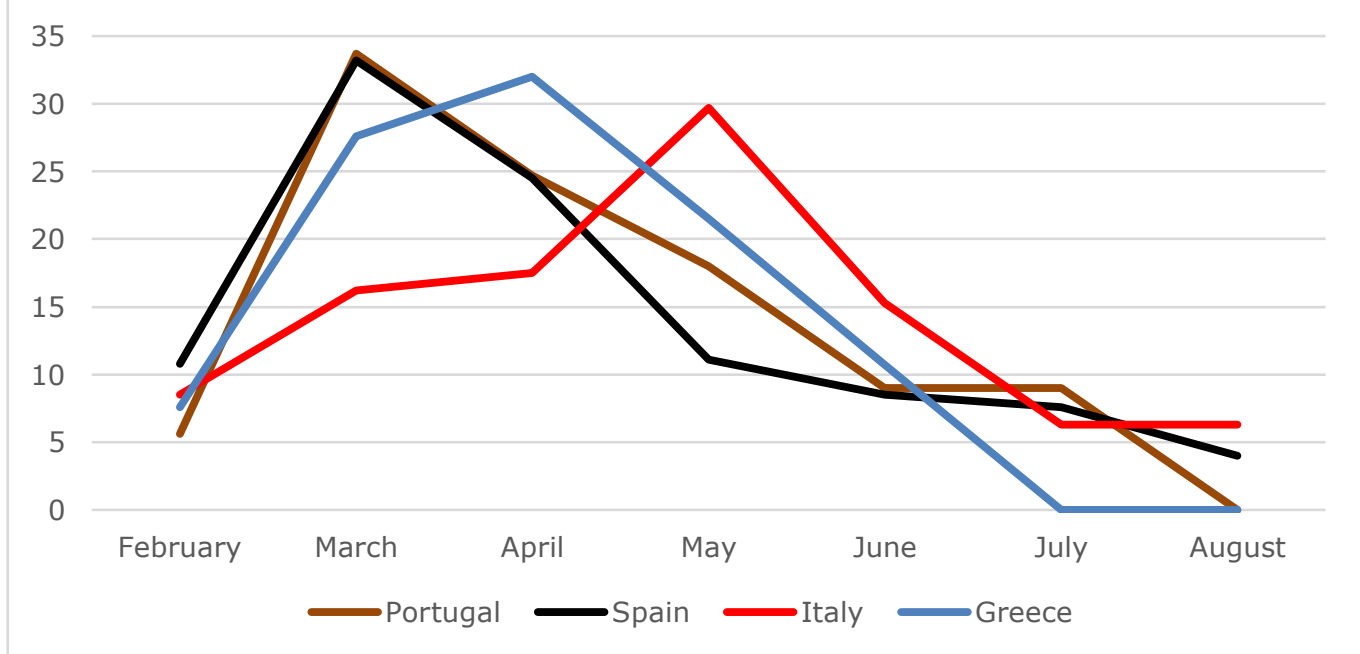

Source: International Fact Checking Network.

The second objective was to analyse the preferred topics during the period in question. From the point of view of the topic categories of disinformation, those related to causes, symptoms and cures were the most frequent in general terms. In Greece they represent $27.6 \%$ and in Portugal $25.8 \%$.

For their part, verifications related to authorities were the most frequent in Spain and Italy, coinciding with the fact that they were the most polarized countries during the pandemic.

In the case of Greece, a particularity is also identified that should be examined in subsequent studies. Up to $50.7 \%$ of the hoaxes were related to conspiracy theories.

Graph 3. Topic categories of disinformation between February and August 2020.

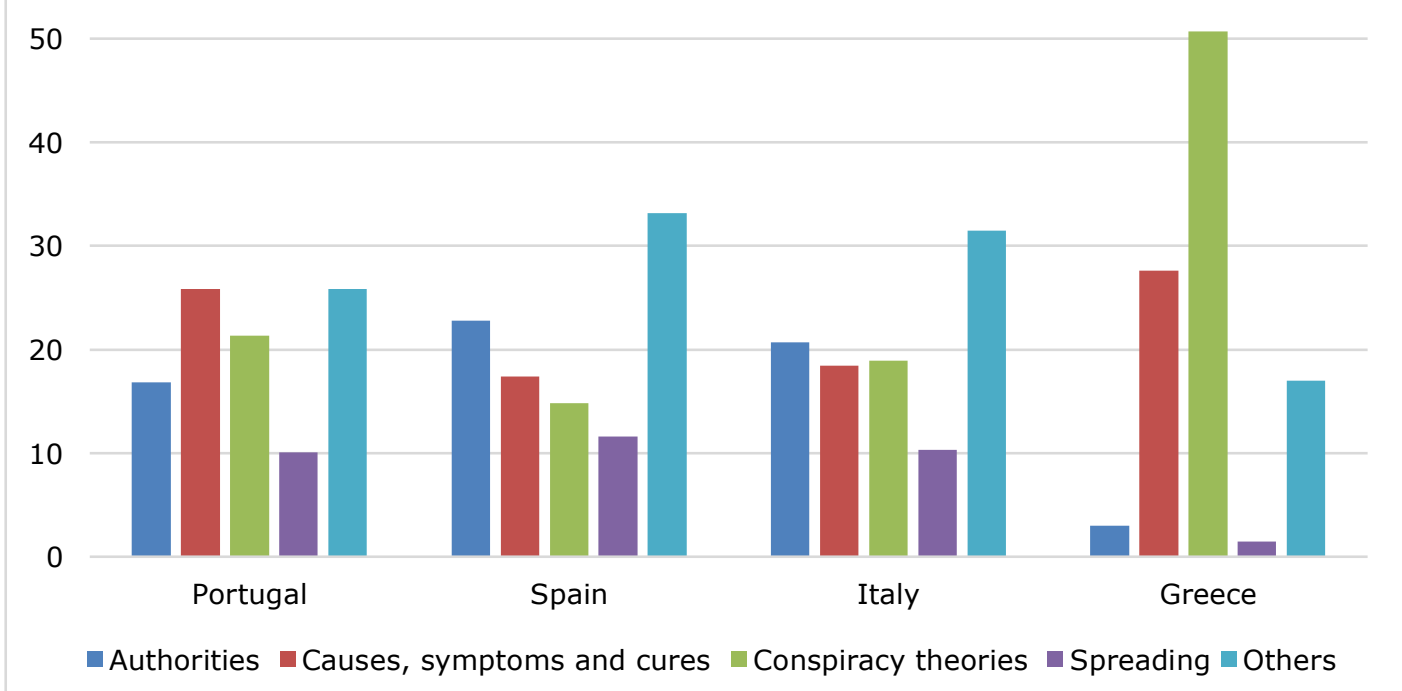

Source: International Fact Checking Network. 
Another element of analysis was the rating, by fact-checkers, of the verified content: the options could be divided into false or misleading. In Portugal and Spain, more than $90 \%$ were identified as false compared to Greece and Italy, where this type of disinformation accounted for 78.5 and $66.6 \%$, respectively.

Graph 4. Qualification of disinformation by country between February and August 2020.

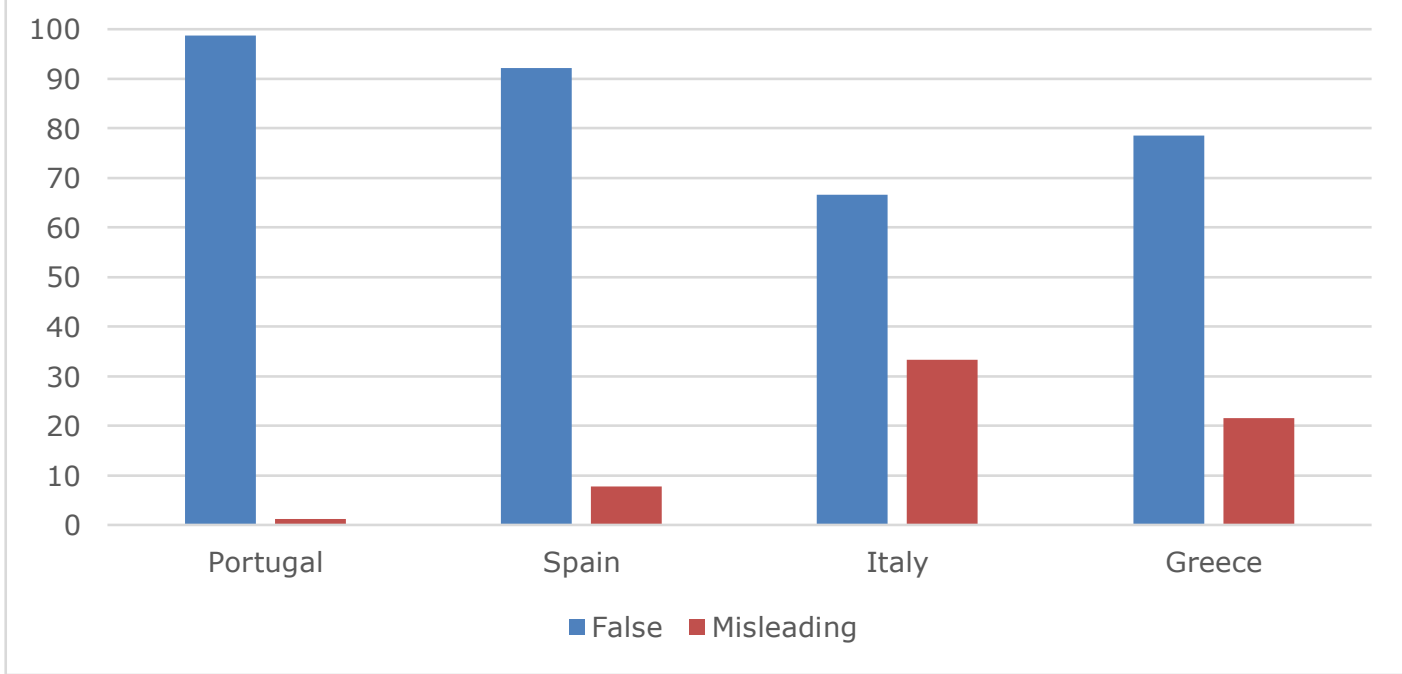

Source: International Fact Checking Network.

From the point of view of the viral spread of hoaxes in other countries, Spain clearly stood out with $17.7 \%$ of hoaxes and Italy with $5 \%$. Neither Greece nor Portugal identified patterns of disinformation replicated in other countries.

Thus, Spain comes across as an exporter of hoaxes. At first this could be assumed to be because its hoaxes are replicated in South America. However, their disinformation (in terms of format, content, etc.) reached the whole world: China, the US, etc.

In this regard, it would be interesting to continue delving into this type of analysis to see which categories, formats and narratives are more likely to be exported.

On the other hand, it is important to note that $34 \%$ of the hoaxes denied by all factcheckers in these four countries were refuted by Maldita and $20 \%$ by Newtral. Facta in Italy with $12.7 \%$ and Elinika Hoaxes in Greece with $6.8 \%$ ranked third and fourth in quantitative terms. This also indicates the professional attitude of these fact-checkers within IFCN and their relevance in giving early warnings of disinformation. 
Graph 5. Viral spread of disinformation abroad by country between February and August 2020

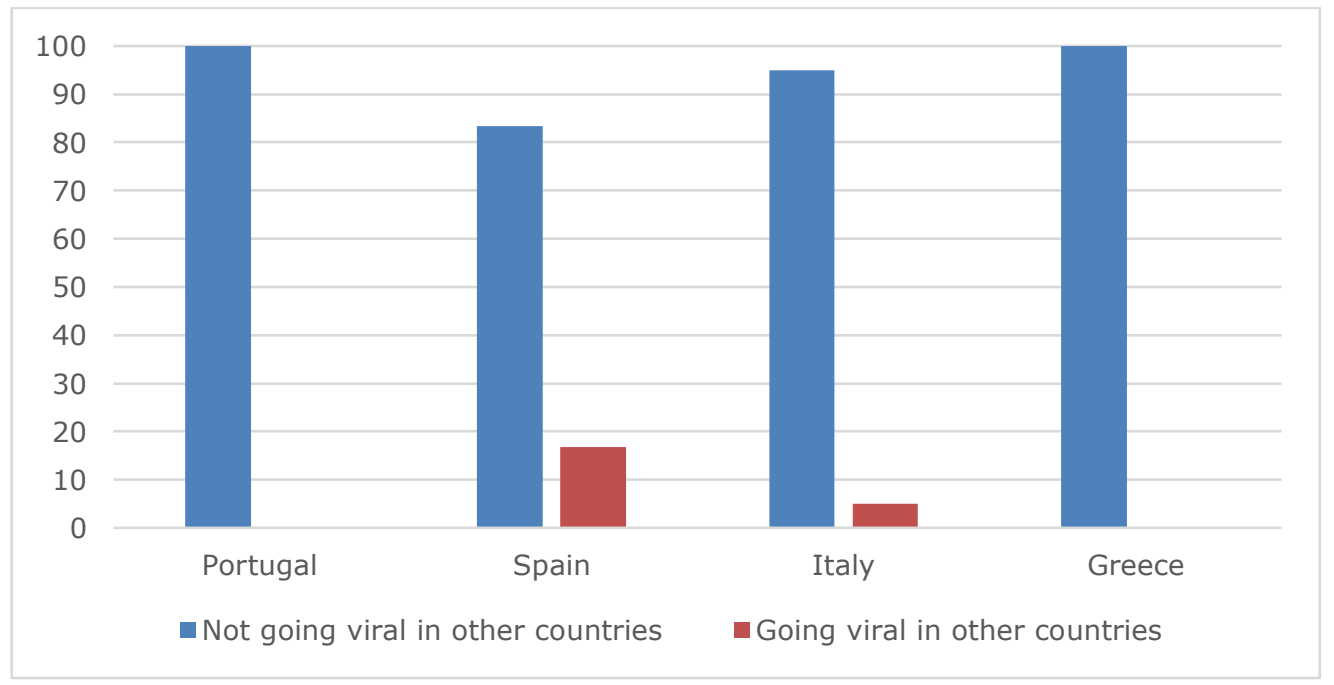

Sources: International Fact Checking Network.

\section{Conclusions and discussion}

The normalization of disinformation processes has been one of the most significant lessons from this pandemic. During the first months, the disinformation focused on 3 main themes from a temporal point of view: the forms of contagion and cure of the virus, the opening measures and political management of the different countries and the issue of vaccines.

Thus, months after the pandemic and disinformation set in permanently - although with different intensities- throughout the world, the different academic works continue to analyse and create theories, correlations, typologies and topics of disinformation related to COVID-19.

Our work confirms previous studies: the greater the information intensity, the greater the disinformation (Paniagua et al., 2020). March was the month with the highest number of hoaxes and the information that reached fact-checking organizations was mostly false.

In this context, Spain stands out, with $61.32 \%$ of hoaxes that circulated in these countries that were verified by fact-checkers. In second place comes, Italy with $22.32 \%$ of disinformation, Portugal with $9.4 \%$ and Greece with $6.94 \%$.

In this regard, and as a first conclusion, it should be noted that during the first 6 months of the pandemic, 3 out of 5 hoaxes that were denied by the fact-checkers of these four European countries were verified by Spanish fact-checkers. According to First Draft, $17.3 \%$ of the disinformation analysed during the first six months of 2020 related to the pandemic was in Spanish, compared to $8.8 \%$ in Portuguese.

From this perspective, those countries with the highest incidence, and also the largest in terms of territory and population, such as Spain and Italy, were the ones that had to deny most of the hoaxes. 
Second, March and April were the most active months from the point of view of disinformation. About 3 out of 5 hoaxes were refuted in Portugal, Spain and Greece during these two months.

Third, there are two axes when identifying the topic categories of disinformation: those related to causes, symptoms and cures were the most frequent in Greece and Portugal. Those related to authorities were the most frequent in Spain and Italy, which were more polarized during the pandemic. Thus, we can highlight a health-preventive axis and another polarized political axis.

In the case of Greece, it is important to note that up to $50.7 \%$ of the hoaxes were related to conspiracy theories.

Fourth, the qualification of the denials by fact-checkers stands out, with the options being divided between false or misleading. In Portugal and Spain, more than $90 \%$ were identified as false compared to Greece and Italy, where this type of disinformation reached $78.5 \%$ and $66.6 \%$, respectively. In this regard, it would be interesting to analyse in detail the internal verification dynamics of fact-checkers in these countries to identify the fact-checking cultures of this type of organization.

Fifth, and from the point of view of the viral spread of hoaxes in other countries, Spain clearly stands out with $17.7 \%$ of hoaxes, and Italy with $5 \%$. Neither Greece nor Portugal had patterns of disinformation replicated in other countries.

We consider that there are two factors that helped Spain exporting hoaxes. On the one hand, the language makes it possible to export hoaxes to Latin America and, on the other hand, the importance of Maldita, and to a lesser extent Newtral, as fact-checkers when it comes to refuting hoaxes at global level.

Based on these results, it could be interesting to continue delving into these typologies to see which categories, formats and narratives are most likely to be exported.

Sixth, we should assess these data with caution as they can measure the effectiveness of verification partnerships rather than the impact of hoax dynamics in different countries. In this regard, it is important to note that $34.5 \%$ of the hoaxes refuted by all fact-checkers in these four countries were disproved by Maldita and $20 \%$ by Newtral, which indicates the relevance of these two verifiers at European level but also the competition dynamics between them.

In conclusion, it should be noted that in Spain there has been a much higher number of hoaxes reproduced than in other countries, because it is a country with many cultures and it is a highly politicized country.

The data also indicates the professional stance of Spanish fact-checkers within IFCN to place themselves as references that send early warnings of disinformation to the rest of the organizations. 


\section{References}

Aguado-Guadalupe, G., \& Bernaola-Serrano, I. (2020). Verificación en la infodemia de la Covid-19. El caso Newtral. Revista Latina, (78), 289-308. https://doi.org/10.4185/RLCS2020-1478

Apuke, O.D., \& Omar, B. (2020). Fake news and COVID-19: Modelling the predictors of fake news sharing among social media users. Telemat. Inform., 101475. https://www.ncbi.nlm.nih.gov/pmc/articles/PMC7390799/

Brennen, J., Simon, F., Howard; P., \& Nielsen, R. K. (2020). Types, Sources, and Claims of COVID-19 Misinformation. Oxford: Reuters Institute for the Study of Journalism. Disponible en: https://reutersinstitute.politics.ox.ac.uk/types-sources-and-claims-covid19-misinformation

Brüggemann, M., Engesser, S., Büchel, F., Humprecht, E., \& Castro, L. (2014). Hallin and Mancini Revisited: Four Empirical Types of Western Media Systems. Journal of Communication, 64 (6), 1037-65. doi:10.1111/jcom.12127.

Büchel, F., Humprecht, E., Castro-Herrero, L., Engesser, S., \& Brüggemann, M. (2016). Building Empirical Typologies with QCA: Toward a Classification of Media Systems. International Journal of Press/Politics, 21 (2), 209-32. doi:10.1177/1940161215626567.

Freeman, D., Waite, F., Rosebrock, L., Petit, A., Causier, C., East, A., Jenner, L., Teale, A-L., Carr, L., Mulhall, S., Bold, E. \& Lambe, S. (2020). Coronavirus Conspiracy Beliefs, Mistrust, and Compliance with Government Guidelines in England. Psychological Medicine. 2020, 1-13. doi:10.1017/S0033291720001890

IFCN (2017). IFCN code of principles report 2018. International Fact-Checking Network. Available at: https://ifcncodeofprinciples.poynter.org/storage/docs/PUBLIC VERSIONCODE OF PRINCIPLES REPORT YEAR 1 REV AM.pdf?V $=1538242914$

Hallin, D. C., \& Mancini, P. (2004). Comparing media systems: Three models of media and politics. Cambridge University Press.

Humprecht, E., Esser, F., \& Van Aelst, P. (2020). Resilience to online disinformation: A framework for cross-national comparative research. International Journal of Press/Politics, 25(3), 493-516.

https://journals.sagepub.com/doi/full/10.1177/1940161219900126

Humprecht, E. (2019). Where 'fake news' flourishes: a comparison across four Western democracies. Information, Communication \& Society, 22(13), 1973-1988. https://doi.org/10.1080/1369118X.2018.1474241

Krause, N.M., Freiling, I., Beets, B., \& Brossard, D. (2020). Fact-checking as risk communication: The multi-layered risk of misinformatino in times of COVID-19. J. Risk Res., 1-8. https://doi.org/10.1080/13669877.2020.1756385

Loomba, S., de Figueiredo, A., \& Piatek, S.J. (2021). Measuring the impact of COVID-19 vaccine misinformation on vaccination intent in the UK and USA. Nat Hum Behav. https://doi.org/10.1038/s41562-021-01056-1 
López-García, X., Costa-Sánchez, C., \& Vizoso, Á. (2021). Journalistic Fact-Checking of Information in Pandemic: Stakeholders, Hoaxes, and Strategies to Fight Disinformation during the COVID-19 Crisis in Spain. Int. J. Environ. Res. Public Health, 18, 1227. https://doi.org/10.3390/ijerph18031227

López-Pan, F., \& Rodríguez-Rodríguez, J. (2020). El fact checking en España. Plataformas, prácticas y rasgos distintivos. Estudios sobre el Mensaje Periodístico, 26 (3), 1045-1065. https://doi.org/10.5209/esmp.65246

Lozano, J. (2008). La comunicación del riesgo y el riesgo de la comunicación. P. Francescutti (ed). Comunicación del riesgo. Comunicación de crisis. Dykinson. Madrid.

Naeem S B, \& Bhatti, R. (2020) The Covid-19 'infodemic': A new front for information professionals. Health Information and Libraries Journal. https://doi.org/10.1111/hir.12311

Nielsen, R. K., Fletcher, R., Newman, N., Brennen, J., \& Howard, P. (2020). Navigating the 'infodemic': how people in six countries access and rate news and information about coronavirus. Reuters Institute. Available at: https://reutersinstitute.politics.ox.ac.uk/infodemic-how-people-six-countries-accessand-rate-news-and-information-about-coronavirus

Papapicco, C. (2020). Informative contagion: The Coronavirus (COVID-19) in Italian journalism. Online Journal of Communication and Media Technologies, 10 (3), e202014.

Paniagua-Rojano, F., Seoane, F., \& Magallón-Rosa, R. (2020). Anatomía del bulo electoral: la desinformación política durante la campaña del 28-A en España. Revista CIDOB d'Afers Internacionals, n.o 124 (april 2020), 123-145. DOI: doi.org/10.24241/rcai.2020.124.1.123

Peña Ascacíbar, G., Bermejo Malumbres, E., \& Zanni, S. (2021). Fact checking durante la COVID-19: análisis comparativo de la verificación de contenidos falsos en España e Italia. Revista De Comunicación, 20(1), 197-215. https://doi.org/10.26441/RC20.12021-A11

Sánchez-Duarte, J.M., \& Magallón-Rosa, R. (2020a). Aprendizajes de pandemia: desinformación y COVID-19. Telos, September, 2020. https://telos.fundaciontelefonica.com/aprendizajes-de-pandemia-desinformacion-ycovid-19/

Sánchez-Duarte, J.M., \& Magallón-Rosa, R. (2020b). Infodemia y COVID-19. Evolución y viralización de informaciones falsas en España. Revista Española de Comunicación en Salud. https://e-revistas.uc3m.es/index.php/RECS/article/view/5417/3923

Salaverría, R., Buslón, N., López-Pan, F., León, B., López-Goñi, I., \& Erviti, M.-C. (2020). Disinformation in times of pandemic: Typology of hoaxes on Covid-19. Prof. Inf., 29, e290315. https://doi.org/10.3145/epi.2020.may.15

Seo, H., \& Faris, R. (2021). Comparative Approaches to Mis/Disinformation| Special Section on Comparative Approaches to Mis/Disinformation - Introduction. International Journal Of Communication, 15, 8. Retrieved from https://ijoc.org/index.php/ijoc/article/view/14799/3376 
Tangcharoensathien, V., Calleja, N., Nguyen, T., Purnat, T., D'Agostino, M., Garcia-Saiso, S., Landry, M., Rashidian, A., Hamilton, C., Abdallah, A., Ghiga, I., Hill, A., Hougendobler, D., Andel, J., Nunn, M., Brooks, I., Sacco, P., Domenico, M., Mai, P., Gruzd, A., Alaphilippe, A., \& Briand, S. (2020). Framework for managing the COVID-19 infodemic: Methods and results of an online, crowdsourced WHO Technical Consultation. Journal of Medical Internet Research, 22, e19659. https://doi.org/10.2196/19659.

Uscinski, J. E., Enders, A. M., Klofstad, C., Seelig, M., Funchion, J., Everett, C., Wuchty, S., Premaratne, K., \& Murthi, M. (2020). Why Do People Believe COVID-19 Conspiracy Theories? Harvard Kennedy School Misinformation Review. doi: $\underline{10.37016 / \mathrm{mr}-2020-015}$.

Vizoso, Á., \& Vázquez-Herrero, J. (2019). Plataformas de fact-checking en español. Características, organización y método. Communication \& Society, 32 (1), 127-144. https://doi.org/10.15581/003.32.1.127-144

World Health Organization. (2020). Novel Coronavirus (2019-nCoV). Situation Report13. World Health Organization. Recuperado de https://www.who.int/docs/defaultsource/coronaviruse/situation-reports/20200202-sitrep-13-ncovv3.pdf?sfvrsn $=195 f 4010 \quad 6$

Wardle, C., \& Derakshan, H. (2017). Information Disorder: Toward an interdisciplinary framework for research and policy making. Council of Europe. https://rm.coe.int/information-disorder-toward-an-interdisciplinary-framework-forresearc/168076277c 